\title{
BEYOND THE BRICK WALLS: HOMESCHOOLING STUDENTS WITH SPECIAL NEEDS
}

\section{KATHLEEN B. COOK, KATIE E. BENNETT, JUSTIN D. LANE, AND THEOLOGIA K. MATARAS}

University of Georgia

\section{Author Note}

Kathleen B. Cook, Department of Communication Sciences and Special Education, University of Georgia; Katie E. Bennett, Department of Communication Sciences and Special Education, University of Georgia; Justin D. Lane, Department of Communication Sciences and Special Education, University of Georgia; and Theologia K. Mataras, Department of Communication Sciences and Special Education, University of Georgia.

The authors wish to acknowledge the support and advisement of Dr. Kristin Sayeski in preparation of this manuscript.

Correspondence concerning this article should be addressed to Kathleen Cook, Department of Communication Sciences and Special Education, 570E Aderhold Hall, University of Georgia, Athens, GA 30602. E-mail: kcook1@uga.edu

\section{ABSTRACT}

The percentage of children with special needs receiving academic instruction at home has substantially increased since a resurgence of homeschooling during the 1990s. In light of this information, the purpose of this article was to provide an overview of the history and laws related to homeschooling, the characteristics of homeschool families, and the relevant issues that parents of children with disabilities encountered when choosing to homeschool. This is followed by a discussion of the reasons parents chose to homeschool their children with special needs, as well as the current state of research on homeschooling students with disabilities. Finally, suggestions related to 
homeschooling students with disabilities were made for future researchers, parents, and public school educators.

Over the past 15 years, data from the National Center for Education Statistics have shown an increasing trend in the numbers of children being educated within the home, including students with disabilities (Bielick, 2008). During the period from 1999 to 2007, the percentage of students with disabilities who were homeschooled increased from 1.8 to $2.6 \%$ (National Center for Education Statistics, 2010). The 2007 National Household Education Surveys Program found that approximately $21 \%$ of homeschooling parents reported "other special needs" and 11\% reported "physical or mental health problems" as important reasons for homeschooling (National Center for Education Statistics, 2007). According to these surveys, homeschooling has increasingly become an educational option for parents with exceptional children.

As more parents of children with disabilities consider homeschooling, this article provides information related to that decision-making process. First, an overview of homeschooling is provided, including a brief history of homeschools in the United States and a summary of laws related to homeschools and special education. Next, relevant issues for parents considering homeschooling are discussed, including characteristics of homeschool students and families, reasons that families have chosen to homeschool their children with disabilities, the benefits and challenges encountered, and the role of the public schools. Then, the current state of research on homeschool students with disabilities is explored. Finally, suggestions are made for future researchers, as well as for parents and public school educators, to consider when planning for the educational needs of children with disabilities at home.

\section{HISTORY OF HOMESCHOOLING IN THE UNITED STATES}

Throughout history, children have been educated at home. However, the industrial revolution of the late 1800s and early 1900s resulted in compulsory U.S. public school attendance legislation, and thus, homeschooling was no longer considered an option for most U.S. families for more than a half-century (Duffey, 1999; Wilhelm \& Firmin, 2009). Homeschool, however, made a resurgence in the 1960s. The rise in homeschools during that time was influenced by many different social and political influences 
including the passage of desegregation laws; removal of prayer from schools; and John Holt's book, How Children Fail, which blamed public schools for failing to educate (Wilhelm \& Firmin, 2009). The number of children being homeschooled steadily increased from the 1960s onward, and by 1993, homeschooling was legal in all 50 states (Wilhelm \& Firmin, 2009). Today's compulsory attendance laws stipulate attendance in public or nonpublic schools_-including homeschools_-and all K-12 programs must be approved by the state (Knickerbocker, 2001). In 2007, the National Household Education Surveys Program estimated that 1.5 million U.S. children, or almost $3 \%$ of school-aged children, received homeschooling (Bielick, 2008).

\section{LAWS AND REGULATIONS}

The U.S. Congress first passed legislation to provide funding for the education of students with disabilities in the 1970s. This legislation has been reauthorized several times over the years and is currently known as the Individuals with Disabilities Education Act (IDEA; Knickerbocker, 2001). Although making a distinction between public and private schools in the disbursement of funds, IDEA did not define what constituted a private school nor did it specifically address funding for students in homeschools. Therefore, decisions on whether to provide funding for special education services to students in homeschools were left to individual states, and many states considered IDEA rights to be forfeited for homeschool students (Knickerbocker, 2001; Lambert, 2001). The U.S. Supreme Court has supported the power of the individual states to make decisions about support of children with disabilities in homeschools. For example, in Hooks v. Clark County School District (1998), the U.S. Supreme Court upheld a Nevada school system's denial of speech therapy services for a homeschool child (as cited in Knickerbocker, 2001). The Supreme Court ruled that individual states have the power to treat a homeschool as either a private school or as a non-school; if categorized as a non-school, a student in a homeschool is not eligible for IDEA services (Knickerbocker, 2001; Lambert, 2001). However, some states such as Arizona, Iowa, North Dakota, and Pennsylvania have homeschool laws that include provisions for students with disabilities (Reinhiller \& Thomas, 1996). The state of Washington allows funding for special services for homeschool students who also attend public schools part time; other states or local education agencies provide special services for homeschool students on a case-by-case basis (Knickerbocker, 2001). Several authors (Duffey, 2002; Knickerbocker, 2001; Lambert, 2001) argued that IDEA should be 
amended to define homeschools as private schools so that services will be available for homeschool students with disabilities. It is notable that the U.S. Office of Special Education Programs has interpreted IDEA's Child Find provisions to be inclusive of children who are being homeschooled, even though services may not be available to eligible children who remain homeschooled (Duffey, 2002). In states that do allow IDEA funds to be used for homeschool students, two additional factors are typically in play: (a) in order to receive services, the parents must also agree to submit to evaluations for their children and work with a team to develop educational plans, thereby giving up some control of their children's educational management; and (b) IDEA funding for all eligible students in non-public schools is not guaranteed (Knickerbocker, 2001).

Whether or not a homeschool student has a disability, the homeschool must comply with its state's compulsory attendance laws (Reinhiller \& Thomas, 1996). Homeschool regulations vary from state-to-state, but most states stipulate that homeschools document some or all of the following: (a) specific qualifications of the home educator, (b) curriculum choices, (c) required number of hours per day and days per year of instructional time, (d) standardized testing, and (e) reports to local school systems (Reinhiller \& Thomas, 1996). The burden for compliance with state homeschool laws and regulations rests on the parents. In sum, parents need to know the local homeschool regulations and the accessibility of special education services for homeschools; a good place to start searching for information is the local school board.

\section{HOMESCHOOL CONSIDERATIONS}

\section{STUDENT AND FAMILY CHARACTERISTICS}

The research literature on homeschooling has shown that students with many different types of disabilities and with varying levels of need have participated in homeschools. Duffey (2002) conducted a national survey of parents who homeschooled their children with disabilities. The top diagnoses of homeschool children reported from 121 surveys were attention deficit hyperactivity disorder (ADHD), learning disabilities (LD), autism spectrum disorder (ASD), and speech-language impairment (Duffey, 2002). However, studies have also chronicled homeschool children with epilepsy (Arora, 2006; Reilly, Chapman, \& O’Donoghue, 2002), visual impairments (Arora, 2006; Parsons \& Lewis, 2010), intellectual disabilities (Kidd \& Kaczmarek, 2010; Parsons \& Lewis, 2010), hearing impairments and deafness (Parks, 2009), and physical disabilities (Loten, 2011; Parsons \& Lewis, 2010; Reilly et al., 2002). In addition, Obeng (2010) reported 
qualitative interviews with two parents of pre-adolescents with severe multiple health problems. Furthermore, a study by Duffey (2002) indicated that parents of students with disabilities tended to take a longer time deciding to remove their children from public school than other homeschool parents. However, once removed, the homeschool students with disabilities were also more likely to receive part time services from public schools than other homeschool students (Duffey, 2002). Another attribute of some homeschool families was that only their children with disabilities were homeschooled, while the siblings continued to attend public school (Olsen, 2008).

Homeschool children with disabilities come from families that are similar to all homeschool families. In a national survey of families who homeschooled children with disabilities, most families were described as white, two-parent (working father and stay-at-home mother), suburban, and with 3.5 children with 1.5 identified as having special needs (Duffey, 2002). In addition, most homeschool students with disabilities received the majority of instruction from their mothers (Arora, 2006; Duffey, 2002; Parks, 2009), even though fathers or other instructors have been reported (Arora, 2006). Duffey (2002) also found that $12 \%$ of mothers were certified teachers, $30 \%$ of which had some training in special education. Parents reported a wide range of educational levels, from high school through master's degrees (Parks, 2009; Parsons $\&$ Lewis, 2010). A very small number of homeschool parents reported having a physical or mental disability themselves (Rothermel, 2011). Collectively, these studies provided a picture of homeschoolers with disabilities and their families; nevertheless, there are many homeschool students and families that will not fall under these broad descriptors.

\section{REASONS FOR HOMESCHOOLING}

Two main philosophical perspectives for homeschooling have traditionally been described as ideological and pedagogical (Higgins, 2008). Initially categorized by Van Galen in 1988 (as cited in Higgins, 2008), Higgins attempted to verify whether homeschool parents could be divided into Van Galen's two discrete groups: ideologues, homeschooling because of religious reasons; or pedagogues, homeschooling to provide different methods of instruction than the schools. Higgins concluded that the philosophical position for most homeschool families indicated an overlap between the two constructs-more often, both principles played a part in the decision to homeschool. The results of studies of homeschool students with disabilities aligned with Higgins' findings: many parents expressed a desire to teach their children from religious 
perspectives (Arora, 2006; Parks, 2009; Parsons \& Lewis, 2010), but more often, the main decision to homeschool was related to a desire to provide better instruction or individualization for their children (Arora, 2006; Duffey, 2002; Hurlbutt, 2011; Loten, 2011; Olsen, 2008; Parks, 2009; Parsons \& Lewis, 2010; Reilly et al., 2002).

Parents with deep philosophical differences with public education may choose to homeschool regardless of the services their children with disabilities could be offered in public school. However, other reasons for homeschooling, frequently rooted in pedagogy, include the perception that the public school has failed to meet a child's needs. That is, the main motivation for many parents to homeschool was that their children's special education needs simply were not being met (Arora, 2006; Duffey, 2002; Hurlbutt, 2011; Olsen, 2008; Parks, 2009; Parsons \& Lewis, 2010; Reilly et al., 2002). For example, a chief concern of parents of children with ASD was that schools were either unwilling or unable to provide therapies or treatments that parents considered effective (Hurlbutt, 2011). In addition, parents also attributed negative experiences with public schools as a deciding factor in choosing to homeschool (Duffey, 2002; Parsons $\&$ Lewis 2010). Other reasons for homeschooling included escape from bullying (Arora, 2006; Parsons \& Lewis, 2010) and avoiding the stigma of a labeled disability (Ensign, 2000; Olsen, 2008). The salient point is that some parents, frustrated with their child's services, choose to homeschool and figure out how to deliver those services on their own. These findings suggest that, especially in school systems that do not have official policies and programs to support homeschool families, public schools could do a better job of outreach, connection, and communication with families to prevent much of the dissatisfaction that has led many parents to choose homeschooling over public schools.

\section{BENEFITS AND CHALLENGES OF HOMESCHOOLING}

A majority of parents across several studies reported satisfaction with their children's progress in homeschools (Duffey, 2002; Kidd \& Kaczmarek, 2010; Rothermel, 2011). Parents specified the benefits of freedom in selecting curriculum, pace of instruction, and daily routines that met their family's and individual children's needs (Ensign, 2000; Hurlbutt, 2011; Loten, 2011). In this era of increased access to technology, many parents reported reliance on Internet sources for instructional support (Parsons and Lewis, 2010). In addition, educational consultants were often used at some point in the homeschool planning process, especially when the child had special needs (Ensign, 2000). Some students were unschooled, meaning they had an unstructured schedule guided by the student's day-to-day learning interests (Loten, 2011). 
However, Arora (2006) found that most of the interviewed families followed a structured daily routine for their children with disabilities. Furthermore, Higgins (2008) related that parents of children with disabilities were significantly more likely to use traditional teaching methods (i.e., parent directed) in homeschooling rather than more loosely structured instruction. Although there has been some indication that homeschool families shift from original values and attitudes over time, becoming more nontraditional the longer they homeschooled (Rothermel, 2011), it is unclear whether families whose children have special needs follow this progression. However, no matter the degree of structure or the method of instruction, parents reported enjoying much more control over their children's education when they homeschooled.

Although parents tended to give high ratings to the overall homeschool experience, many reported challenges with homeschooling students with disabilities. Some families described a lack of emotional, social, and moral support from outside sources (Arora, 2006; Obeng, 2010). When support was found, it was more likely to be from other homeschool families and organized homeschool groups than from public schools (Arora, 2006; Parsons \& Lewis, 2010). In interviews with two parents who homeschooled their children with severe multiple health problems, Obeng (2010) found that parents did not receive enough professional and social support, and as a result, the parents were feeling overwhelmed with sadness and frustration. While many other factors may influence the intensity of homeschooling challenges, certainly the severity of the child's needs and the amount of support available to the family are two major components that will affect the success of the homeschool program.

Although a commonly stated concern related to homeschooling was that students might have limited social interactions, most parents reported feeling satisfied with the socialization opportunities afforded their children from homeschool groups, sports, and religious services (Kidd \& Kaczmarek; 2010; Loten, 2011; Parks, 2009; Parsons \& Lewis, 2010). However, very few researchers gathered information directly from the homeschool students with disabilities about their perspectives on socialization. In one study that included interviews with homeschool adolescent females with LD, all three participants reported feeling uncomfortable in social situations (Loten, 2011). The first participant, an adolescent girl who also had a physical disability, reported struggling to make friends even though she had plenty of opportunities to socialize. The second adolescent reported not feeling a part of her peer group because of her learning deficits, and the third adolescent reported feelings of peer isolation because her family lived in a rural area. While it is possible that these teens would have felt the same awkwardness or isolation in a public school setting, socialization might remain an area of legitimate concern for many homeschool students and their parents. 


\section{ROLE OF PUBLIC SCHOOLS}

Unfortunately, there often seems to be disconnect between public schools and homeschools. For example, an interview of educators in Canadian schools indicated mostly negative opinions about students that had been removed from their schools for homeschooling (Olsen, 2008). Administrators reported being aware that parents probably did not share their real reasons for choosing to homeschool, but also expressed frustration with parents for not working with the school to resolve problems. Conversely, parents reported not feeling genuinely welcomed to ask for support from schools, even though some administrators offered part time classes and the opportunity to reenroll students. In addition, teachers reported feeling personally offended when parents removed their children from school. Teachers' perceptions were that students tended to reenter public schools after a period of homeschooling with greater academic and social deficits (Olsen, 2008). Overall, most of the educators reported negative views on homeschooling (Olsen, 2008). Such negative attitudes about homeschooling seem to be pervasive across many educators and educational groups, including the National Education Association. An organization supporting public education, the National Education Association has issued resolutions over the past several years stating that homeschools with parents as instructors are inadequate educational programs (National Educational Association, 2013).

As noted earlier, parents reported many reasons for choosing to educate children with disabilities at home, but frequently, unhappiness with the schools was a main motivation. In a personal account of her experiences homeschooling her son with an ASD, Sofia (2010) described her frustrations with her son's fourth grade teachers. Sofia felt that the teachers expected all students to have normal behavior and placed inordinately high value on student compliance as a measure of success. Rather than providing differentiated instruction, teachers blamed her son's inappropriate behavior for his lack of progress. After removing her son from school, Sofia employed the services of a certified teacher for curriculum advice, based homeschool lessons on her son's areas of interest, and provided her son explicit instruction on social rules. Sofia reported that her son successfully reentered the public school system the following school year.

It is important to note that not all school systems fail to support of homeschools. One example of a school system providing homeschooling services is the Des Moines Public Schools Home Instruction Program (Des Moines Public Schools, 2013). The Des Moines Public School System was one of the first in the United States to offer a cooperative home-school partnership for homeschooling families (Duffey, 1999). There are other home-school partnerships in existence, and it seems that they may present a viable solution to 
support children with disabilities in homeschools. Funding special education services for homeschool students can offer support for families as well as special education services for students, and can potentially provide a seamless reentry for students who elect to return after a year or two of homeschooling. Even though parents of children with disabilities may have high expectations of the educational system, schools might prevent families from withdrawing due to dissatisfaction by developing a better understanding of student and family needs, and promoting stronger outreach.

\section{CURRENT STATE OF HOMESCHOOLING RESEARCH}

A recent comprehensive literature review evaluated homeschooling in general (Kunzman \& Gaither, 2013). Results of the review indicated that most research on homeschooling was qualitative in design (e.g., surveys, case studies, and personal interviews) and conducted within the United States. Kunzman and Gaither (2013) attributed the dearth of quantitative research to varying state regulations and recordkeeping requirements, which created difficulties in comparing existing state databases. Kunzman and Gaither also contended that, although a few large group studies have reported high academic achievement in homeschool students, the validity of experimental research results may be questionable. For example, in studies by Home School Legal Defense Association and the National Home Education Research Institute, research designs did not employ random sampling methods, and homeschool volunteers provided self-reports of achievement test scores (Kunzman \& Gaither, 2013).

As in the Kunzman and Gaither (2013) review on homeschools, most of the existing research on homeschool students with disabilities used qualitative or mixed method research designs. In addition, the most common method for gathering data was parent interview or survey. The qualitative and mixed method research design studies largely reported on parent motivation and rationale for homeschooling; many also discussed other homeschool issues such as the level of education of the instructor-parent, the structure of the school day and teaching methods used, opportunities to socialize, and overall perception of whether the homeschool experience was successful. Only two studies collected information directly from homeschool students (see Ensign, 2000; Loten, 2011).

It is notable that there have not been any studies using true experimental research designs that examine the efficacy of homeschooling students with disabilities. However, two quasi-experimental exploratory studies supported the effectiveness of parents as instructors of their children with disabilities in a 
homeschool setting. The first exploratory study was conducted with children with LD (Duvall, Ward, Greenwood, \& Delquadri, 1997). Participating students were comprised of one middle school and three elementary level students who were paired with counterpart peers of similar ages, demographic descriptions, and abilities in public school. The duration of student engagement in academic tasks was collected over seven observations in both settings, and pretest-posttest standardized achievement tests were administered to both groups of students. Duvall et al. (1997) determined that homeschool students with LD were on task and engaged in work activities approximately two-anda-half times more than their counterparts in a general education classroom. Pretest to posttest comparisons also indicated that homeschool students made more progress in reading and written language than their public school peers, and made equivalent progress in math. Duvall et al. (1997) attributed the progress of the homeschool students to the higher rate of interaction with the parent-instructor and the greater degree of individualized attention provided in the homeschool setting.

Several years later, Duvall, Delquadri, and Ward (2004) replicated the earlier exploratory study with students with ADHD instead of LD. Two homeschool students with ADHD were paired with two similar students in the public school setting. Both groups of students were observed once a month for five months to collect academic engagement time data. Results indicated that the homeschool students with ADHD were academically engaged at higher rates than their counterparts, and their reading and math gains were greater or equal to their public school peers. Overall, Duvall et al. (2004) posited that study results supported the effectiveness of untrained parents as homeschool instructors of their children with disabilities; however, the parents of children with ADHD reported doubts about their effectiveness as instructors (Duvall et al., 2004).

\section{CONCLUSION}

\section{FUTURE RESEARCH}

Considering the limited research on the efficacy of homeschool students with disabilities - physical disabilities, in particular - there is a need for further study on the effects of homeschooling on the academic, social, and quality of life of students with disabilities. Although there may be challenges to conducting true experimental research, more research using systematic and tightly controlled quasi-experimental designs is warranted. Valuable information can be gleaned from evaluating homeschool variables such as student disabilities, level of parent education and training, curriculum, online programs, 
and professional supports (e.g., tutors, therapists) on student outcomes. More qualitative and quantitative research is warranted to describe and evaluate programs such as the Des Moines Public Schools Home Instruction Program (Des Moines Public Schools, 2013), including the participating students, the services offered, parent satisfaction, and student progress. A comprehensive list of states and local systems that offer services to homeschool students with disabilities would be also be of value to parents of students with disabilities. Furthermore, more research is needed on student perspectives and on longterm academic and social outcomes. (Arora, 2006; Duvall et al., 2004; Duvall et al., 1997; Parks, 2009). Lastly, more research is necessary on homeschool children with specific disabilities, such as children who are deaf or hard of hearing (Parks, 2009), and children with physical, health, and multiple disabilities.

\section{PERSPECTIVES OF PARENTS WHO HOMESCHOOL CHILDREN WITH DISABILITIES}

Many parents reported success homeschooling their children with disabilities, but others described the difficulties and the lack of support from the schools and the community. Some school systems provide part time services for students with disabilities, but many states do not support students that are in a homeschool setting. Parents need to be aware of the regulations and services available in their locales, and they need to explore the benefits and challenges of homeschooling before making the decision to homeschool a student with disabilities.

A common conclusion among studies was that a collaborative relationship between homeschools and school systems would be beneficial for students with disabilities (Arora, 2006; Duffey, 2002; Olson, 2008; Parks, 2009; Parsons \& Lewis, 2010; Reilly et al., 2002; Stevens \& Blair, 1997). Other researchers concluded that public schools might prevent some loss of students to homeschools by increasing individualized instruction (Loten, 2011; Parsons $\&$ Lewis, 2010). Of special concern are families whose children have severe disabilities. Obeng (2010) concluded that parents who homeschool children with extensive medical needs would also benefit from psychotherapy and other supports to maintain their own health. Kunzman and Gaither (2013), in their review of homeschools, reported that the trend seems to be moving in favor of greater access to public schools, with 22 states reporting some accommodations for homeschoolers and only six states refusing to support homeschools. Offering part time special education services might facilitate connection with the homeschool community, and may result in the decreased exodus of students with disabilities due to parental dissatisfaction. 
In conclusion, making the decision to homeschool a child with a disability requires thoughtful deliberation. Some of the many benefits of homeschooling are greater parent involvement, a strengthening of the family unit, opportunities for more natural learning experiences, increased self esteem in students with disabilities, increased individualization and student paced learning, and increased flexibility with family schedules (Peterson, 2009; Romanowski, 2001). However, the challenges include making curriculum decisions, managing finances, accessing special education services, facilitating socialization opportunities, and finding connections with other parents for support. In light of the increasing number of families choosing to homeschool, increased support in the form of special education services from the public schools would serve to improve the homeschooling experiences of many students with disabilities. In addition, if quality research begins to indicate that homeschooling can be done effectively, our legal and educational systems may become more willing to provide a continuum of special education support services. Furthermore, with improved relationships between public schools and families of children with disabilities, parents will choose to homeschool for the right reasons-not as an escape from the school system. The end result will be considered a win for both sides, and more importantly, for the children.

\section{REFERENCES}

Arora, T. (2006). Elective home education and special educational needs. Journal of Research in Special Educational Needs, 6(1), 55-66.

Bielick, S. (2008). 1.5 million homeschooled students in the United States in 2007. National Center for Education Statistics Institute of Education Sciences. http://nces.ed.gov/pubsearch/pubsinfo.asp?pubid=2009030

Des Moines Public Schools. (2013). Home Instruction Program. Retrieved from http://www.dmschools.org/departments/teaching-learning/ home-instruction/

Duffey, J. (1999). Home schooling and students in special education: Sorting out the options for parents. Preventing School Failure, 43(2), 57-63.

Duffey, J. (2002). Home schooling children with special needs. Journal of Special Education Leadership, 15, 25-32.

Duvall, S. F., Delquadri, J. C., \& Ward, D. L. (2004). A preliminary investigation of the effectiveness of homeschool instructional environments for students with attention-deficit/hyperactivity disorder. School Psychology Review, 33, 140-158.

Duvall, S. F., Ward, D. L. Greenwood, C. R., \& Delquadri, J. C. (1997). An exploratory study of home school instructional environments and 
their effects on the basic skills of students with learning disabilities. Education \& Treatment of Children, 20, 150-72.

Ensign, J. (2000). Defying the stereotypes of special education: Homeschool students. Peabody Journal of Education, 75, 147-158.

Higgins, C. (2008). Pilot study: Homeschooling parents' motivations and pedagogy. Unpublished manuscript. Department of Sociology, Humboldt State University, Arcata, California. Retrieved from http://www.humboldt.edu/sociology/downloads/senior_projects/2008_Higgins.pdf

Hurlbutt, K. (2011). Experiences of parents who homeschool their children with autism spectrum disorders. Focus on Autism and Other Developmental Disabilities, 26, 239-249.

Kidd, T. \& Kaczmarek, E. (2010). The experiences of mothers home educating their children with autism spectrum disorders. Issues in Educational Research, 20, 257-275.

Knickerbocker, L. R. (2001). The education of all children with disabilities: Integrating home-schooled children into the Individuals with Disabilities Education Act. Ohio State Law Journal, 62, 1515-1542.

Kunzman, R. \& Gaither, M. (2013). Homeschooling: A comprehensive survey of the research. Other Education: The Journal of Educational Alternatives, 2, 4-59.

Lambert, S. A. (2001). Finding the way back home: Funding for home school children under IDEA. Columbia Law Review, 101, 1709-1729.

Loten, S. (2011). Melissa, Trisha, and Ruth: Hearing the voices of three home schooled adolescents with learning disabilities (Master's thesis). Retrieved from http://hdl.handle.net/1974/6693

National Center for Education Statistics. (2007). Parent and Family Involvement in Education Survey of the 2007 National Household Education Surveys Program (NHES). U.S. Department of Education. Retrieved from http://nces.ed.gov/programs/coe/tables/table-hsc-2.asp

National Center for Education Statistics. (2010). Digest of education statistics: Table 41. Retrieved from http://nces.ed.gov/programs/digest/ d11/tables/dt11_041.asp

National Educational Association. (2013). 2012-1013 NEA resolutions: Home Schooling (Resolution No. B-82). Retrieved from http://www.nea.org/ resolutions

Obeng, C. (2010). A study of the experiences of parents with home-schooled pre-adolescent children with severe multiple health problems. International Journal of Special Education, 25, 80-86.

Olsen, N. B. (2008). Understanding parental motivation to home school: A qualitative case study. Dissertation Abstracts International Section A: Humanities and Social Science, 69(5-A), 1623. 
Parks, E. S. (2009). Deaf and hard of hearing homeschoolers: Sociocultural motivation and approach. Work Papers of the Summer Institute of Linguistics, University of North Dakota Session, 49. Retrieved from http://www.und.edu/dept/linguistics/wp/2009Parks.PDF

Parsons, S. \& Lewis, A. (2010). The home-education of children with special needs or disabilities in the UK: Views of parents from an online survey. International Journal of Inclusive Education, 14, 67-86.

Peterson, D. (2009). You can homeschool your child with special needs. Exceptional Parent, 39(5), 38-39.

Reilly, L., Chapman, A., \& O'Donoghue, T. (2002). Home schooling of children with disabilities. Queensland Journal of Educational Research, 18. Retrieved from http://www.iier.org.au/qjer/qjer18/reilly.html

Reinhiller, N. \& Thomas, G. J. (1996). Special education and home schooling: How laws interact with practice. Rural Special Education Quarterly, 15(4), 11-17.

Romanowski, M. H. (2001). Common arguments about the strengths and limitations of home schooling. Clearing House, 75, 70-83.

Rothermel, P. (2011). Setting the record straight: Interviews with a hundred British home educating families. Journal of Unschooling and Alternative Learning, 5, 20-57.

Sofia, C. A. (2010). Bringing lessons from homeschool to the writing classroom. English Journal, 100, 98-104.

Stevens, S. H. \& Blair, J. F. (1997). Homeschooling LD/ADD children: Great idea or big mistake? LDonline. Retrieved from http://www.ldonline.org/ article/Homeschooling_LD/ADD_Children\%3A_Great_Idea_or_Big _Mistake\%3F?theme=print

Wilhelm, G. M. \& Firmin, M. W. (2009). Historical and contemporary developments in home education. Journal of Research on Christian Education, 18, 303-315. 


\section{APPENDIX}

References with digital object identifier (DOI) numbers added:

Arora, T. (2006). Elective home education and special educational needs. Journal of Research in Special Educational Needs, 6(1), 55-66. http://dx.doi.org/10.1111/j.1471-3802.2006.00059.x

Bielick, S. (2008). 1.5 million homeschooled students in the United States in 2007. National Center for Education Statistics Institute of Education Sciences. http://nces.ed.gov/pubsearch/pubsinfo.asp?pubid=2009030

Des Moines Public Schools. (2013). Home Instruction Program. Retrieved from http://www.dmschools.org/departments/teaching-learning/home-instruction/ http://dx.doi.org/10.1080/10459889909603303

Duffey, J. (1999). Home schooling and students in special education: Sorting out the options for parents. Preventing School Failure, 43(2), 57-63.

Duffey, J. (2002). Home schooling children with special needs. Journal of Special Education Leadership, 15, 25-32.

Duvall, S. F., Delquadri, J. C., \& Ward, D. L. (2004). A preliminary investigation of the effectiveness of homeschool instructional environments for students with attention-deficit/hyperactivity disorder. School Psychology Review, 33, 140-158.

Duvall, S. F., Ward, D. L. Greenwood, C. R., \& Delquadri, J. C. (1997). An exploratory study of home school instructional environments and their effects on the basic skills of students with learning disabilities. Education \& Treatment of Children, 20, 150-72.

Ensign, J. (2000). Defying the stereotypes of special education: Homeschool students. Peabody Journal of Education, 75, 147-158. http://dx.doi.org/10.1080/0161956X.2000.9681939

Higgins, C. (2008). Pilot study: Homeschooling parents' motivations and pedagogy. Unpublished manuscript. Department of Sociology, Humboldt State University, Arcata, California. Retrieved from http://www.humboldt.edu/sociology/downloads/senior_projects/2008_Higgins.pdf

Hurlbutt, K. (2011). Experiences of parents who homeschool their children with autism spectrum disorders. Focus on Autism and Other Developmental Disabilities, 26, 239-249. http://dx.doi.org/10.1177/1088357611421170

Kidd, T. \& Kaczmarek, E. (2010). The experiences of mothers home educating their children with autism spectrum disorders. Issues in Educational Research, 20, 257-275. 
Knickerbocker, L. R. (2001). The education of all children with disabilities: Integrating home-schooled children into the Individuals with Disabilities Education Act. Ohio State Law Journal, 62, 1515-1542.

Kunzman, R. \& Gaither, M. (2013). Homeschooling: A comprehensive survey of the research. Other Education: The Journal of Educational Alternatives, 2, 4-59.

Lambert, S. A. (2001). Finding the way back home: Funding for home school children under IDEA. Columbia Law Review, 101, 1709-1729. http://dx.doi.org/10.2307/1123812

Loten, S. (2011). Melissa, Trisha, and Ruth: Hearing the voices of three home schooled adolescents with learning disabilities (Master's thesis). Retrieved from http://hdl.handle.net/1974/6693

National Center for Education Statistics. (2007). Parent and family involvement in education: Survey of the 2007 National Household Education Surveys Program (NHES). U.S. Department of Education. Retrieved from http://nces.ed.gov/programs/coe/tables/table-hsc-2.asp

National Center for Education Statistics. (2010). Digest of education statistics: Table 41. Retrieved from http://nces.ed.gov/programs/digest/d11/tables/dt11_041.asp

National Educational Association. (2013). 2012-1013 NEA resolutions: Home schooling (Resolution No. B-82). Retrieved from http://www.nea.org/resolutions

Obeng, C. (2010). A study of the experiences of parents with home-schooled preadolescent children with severe multiple health problems. International Journal of Special Education, 25, 80-86.

Olsen, N. B. (2008). Understanding parental motivation to home school: A qualitative case study. Dissertation Abstracts International Section A: Humanities and Social Science, 69(5-A), 1623.

Parks, E. S. (2009). Deaf and hard of hearing homeschoolers: Sociocultural motivation and approach. Work Papers of the Summer Institute of Linguistics, University of North Dakota Session, 49. Retrieved from http://www.und.edu/dept/linguistics/wp/2009Parks.PDF

Parsons, S. \& Lewis, A. (2010). The home-education of children with special needs or disabilities in the UK: Views of parents from an online survey. International Journal of Inclusive Education, 14, 67-86. http://dx.doi.org/10.1080/13603110802504135

Peterson, D. (2009). You can homeschool your child with special needs. Exceptional Parent, 39(5), 38-39.

Reilly, L., Chapman, A., \& O’Donoghue, T. (2002). Home schooling of children with 
disabilities. Queensland Journal of Educational Research, 18. Retrieved from http://www.iier.org.au/qjer/qjer18/reilly.html

Reinhiller, N. \& Thomas, G. J. (1996). Special education and home schooling: How laws interact with practice. Rural Special Education Quarterly, 15(4), 11-17.

Romanowski, M. H. (2001). Common arguments about the strengths and limitations of home schooling. Clearing House, 75, 70-83. http://dx.doi.org/10.1080/00098650109599241

Rothermel, P. (2011). Setting the record straight: Interviews with a hundred British home educating families. Journal of Unschooling and Alternative Learning, 5, 20-57.

Sofia, C. A. (2010). Bringing lessons from homeschool to the writing classroom. English Journal, 100, 98-104.

Stevens, S. H. \& Blair, J. F. (1997). Homeschooling LD/ADD children: Great idea or big mistake? LDonline. Retrieved from http://www.ldonline.org/article/Homeschooling_LD/ADD_Children\%3A_Great_I dea_or_Big_Mistake\%3F?theme=print

Wilhelm, G. M. \& Firmin, M. W. (2009). Historical and contemporary developments in home education. Journal of Research on Christian Education, 18, 303-315. http://dx.doi.org/10.1080/10656210903333442 